\title{
PROSEDUR IMPLEMENTASI PRINSIP-PRINSIP GOOD CORPORATE GOVERNANCE DALAM PROGRAM CORPORATE SOCIAL RESPONSIBILITY PADA PERUSAHAAN DAERAH PDAM KABUPATEN BANTUL
}

\author{
Agus Abdurahman', Reza Widhar Pahlevi² \\ ${ }^{1}$ Fakultas Ekonomi, Universitas Islam Indonesia \\ gusdur62@gmail.com \\ ${ }^{2}$ Fakultas Ekonomi, Universitas Islam Indonesia \\ rezawidharp@gmail.com
}

\begin{abstract}
The purpose of this research is to know the implementation procedure of good corporate governance (GCG) principles in Corporate Social Responsibility (CSR) program, through the identification of stakeholders, namely commissioners, directors, and stakeholders; investivigasi GCG operational framework, and explore the procedures and implementation of GCG principles in CSR programs. The approach used in this research is qualitative approach, that is triangulation test and objectivity test. The data collection technique used interview technique, where the source of irisis comes from three stakeholders. Further analysis is performed in accordance with triangulation test approach and objectivity test. The results show that 1) Board of commissioners, directors, and stakeholders have their respective roles in the framework of developing the operational framework of GCG in PDAM Bantul. Stakeholders in PDAM Bantul play a role in mutual supervision between one party with other parties so that the company can survive in running Good Corporate Governance (GCG). 2) The design of GCG operational framework implemented by PDAM Bantul can not be separated from the close relationship between stakeholders and Corporate Social Responsibility (CSR). Stakeholders play an important role in order to formulate, develop, and implement CSR programs. In preparing the CSR program that will be implemented by PDAM Bantul, the stakeholders are also strongly supported by the application of GCG principles which are also based on the Deloitte Governance model, making it easier for PDAM Bantul to implement a well-designed CSR program. 3) PDAM Bantul from the point of view using the Deloitte Governance model has been able to manage the nine elements well so that the Good Corporate Governance (GCG) practices of PDAM Bantul well done and moreover well the application of GCG principles, the CSR program designed by PDAM Bantul can Well done.
\end{abstract}

Keywords: Corporate governance dan corporate social responsibility

(c) 2018 JBTI. All rights reserved

Article history : received 10 Jan 2018; revised 21 Jan 2018 ; accepted 29 Jan 2018

\section{PENDAHULUAN}

Kinerja PDAM Bantul sampai dengan tahun 2017 adalah masuk kategori Badan Usaha Milik Daerah (BUMD) dengan peringkat baik dan sehat. Kinerja yang sangat baik, menunjukkan manajemen memiliki kapasitas dalam mengimplemantasikan prinsip-prinsip good corporate governance, yang ditunjukkan dengan kinerja secara keseluruhan dan kegiatan spesifik corporate sosial responsibility. Namun demikian dari hasil observasi awal manajemen menginginkan peningkatan kinerja dan penguatan good corporate governance. Kinerja PDAM Bantul sebagai BUMD dengan peringkat baik dan sehat, telah menunjukkan arah yang benar sesuai dengan visi dan misi PDAM Bantul, yaitu menjadi PDAM yang sehat dan mandiri, dengan misi memberikan pelayanan prima kepada pelanggan, profesionalisme SDM, kerjasama dengan mitra terkait (stakeholder), ketersediaan sarana dan prasarana air minum berkualitas, tatakelola keuangan untuk pertumbuhan, serta operasional perusahaan dengan prinsip ekonomi perusahaan. PDAM Bantul 
sedang mengupayakan kemandirian, dimana PDAM Bantul mampu mencapai kemandirian finansial dan tidak sepenuhnya bergantung pada bantuan Pemerintah Kabupaten Bantul. Aspek kemandirian yang menjadi bagian yang tidak terpisahkan dari visi PDAM Bantul, harus sepenuhnya diterjemahkan dalam misi yang mampu mewujudkan kemandirian. Salah satu misi strategis yang telah ditetapkan adalah tata kelola keuangan untuk pertumbuhan atau good corporate governance (GCG) bidang keuangan untuk pertumbuhan, yang pada gilirannya dapat menjadi titik tolak penerapan prinsip-prinsip GCG dari semua fungsi manajemen. Pada penelitian ini, model kerangka kerja governance menggunakan model Deloitte. Model kerangka kerja yang digunakan pada model Deloitte adalah resiko dan budaya. Budaya perusahaan disini juga termasuk budaya sadar resiko, budaya kepatuhan dan etika. Secara umum, model kerangka kerja governance model Deloitte terdiri dari board governance dan corporate governance infrastructure. Board governance merupakan tugas yang tidak dapat dilegasikan kepada manajemen karena merupakan akuntabilitas dari Board, sedangkan corporate governance infrastructure merupakan tugas yang dapat dilegasikan kepada manajemen dan untuk itu board akan berperan sebagai pengawas dari pelaksanaannya (board oversight).

Pada saat ini PDAM Bantul telah menyelenggarakan kegiatan corporate social responsibility (CSR), sebagai wujud kegiatan dalam rangka mencapai visi kemandirian melalui GCG. Untuk memastikan tercapainya visi kemandirian sangat perlu dilakukan pendekatan secara keseluruhan terhadap upaya mengembangkan kerangka operasionalisasi GCG yang secara explisit menjadi bagian dari perencanaan stratejik dan dapat menunjukkan peran dewan komisaris, direksi dan stakeholder. Selanjutnya kerangka operasionalisasi GCG yang dikembangkan, dapat menggambarkan atau memproyeksikan prosedur implementasi prinsip-prinsip GCG dalam kegiatan CSR. Berdasarkan uraian diatas, maka rumusan masalah yang diajukan adalah bagaimana peran dewan komisaris, direksi, dan stakeholder dalam pengembangan kerangka operasional GCG; bagaimana design kerangka operasional GCG yang ditujukan pada kegiatan CSR; Bagaimana prosedur dan implementasi GCGdalam kegiatan CSR.

\section{TINJAUAN PUSTAKA}

\section{Model Kerangka Kerja Corporate Governance}

Pada penelitian ini, model kerangka kerja governance menggunakan model Deloitte. Model kerangka kerja yang digunakan pada model Deloitte adalah resiko dan budaya. Budaya perusahaan disini juga termasuk budaya sadar resiko, budaya kepatuhan dan etika. Secara umum, model kerangka kerja governance model Deloitte terdiri dari board governance dan corporate governance infrastructure. Board governance merupakan tugas yang tidak dapat dilegasikan kepada manajemen karena merupakan akuntabilitas dari Board, sedangkan corporate governance infrastructure merupakan tugas yang dapat dilegasikan kepada manajemen dan untuk itu board akan berperan sebagai pengawas dari pelaksanaannya (board oversight). Berikut ini model Deloitte governance (Susilo, 2017) :

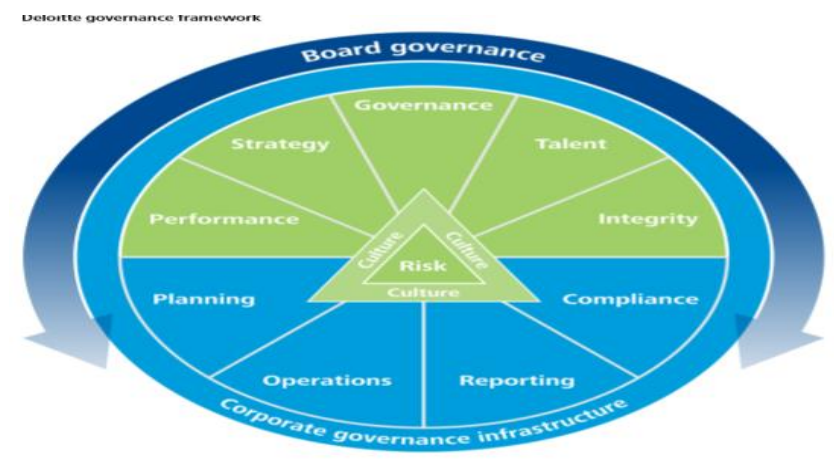

Gambar 1. Model Kerangka Kerja Corporate Governance Model Deloitte 
Penjelasan dari model tersebut adalah :

1. Inti dari model ini adalah budaya perusahaan dan resiko, yang akan mempengaruhi ataupun berdampak pada efektivitas dari seluruh elemen kerangka kerja. Keberhasilan dan kegagalan perusahaan sering kali sangat ditentukan bagaimana mereka mengelola paparan resiko yang dihadapinya karena itu budaya mengelola resiko menjadi inti dari kerangka kerja governance

2. Corporate governance infrastructure merupakam keseluruhan model operasional perusahaan yang melibatkan orang, proses dan teknologi. Ini adalah bagaimana cara manajemen melaksanakan pengelolaan perusahaan melalui tahapan perencanan, pelaksanaan, pelaporan dan tetap dalam koridor kepatuhan terhadap hukum dan peraturan perundangan serta norma yang berlaku. Pelaporan ini disampaikan kepada board dan pihak eksternal sesuai dengan aturan yang berlaku. Peran dari Board pada bagian ini adalah lebih kepada pengawasan aktif dan bukan sebagai pelaku.

3. Board governance adalah area di mana board tidak cukup hanya memahami bagaimana hal ini harus dilaksanakan tetapi merupakan area di mana Board bertanggung jawab dan harus terlibat aktif, serta tidak dapat didelegasikan begitu saja kepada manajemen. Hal ini adalah governance, strategi, kinerja, integritas, kaderisasi dan risk governance.

a) Governance: Board harus menetapkan suatu struktur dan proses agar dapat menunaikan tugas dan tanggung jawabnya antara lain dengan mempertimbangkan sudut pandang investor, regulator dan manajemen. Anggota Board harus dipilih melalui proses yang independen, inklusif dan selaras dengan misi dan strategi perusahaan

b) Strategi: Board memberi saran kepada manajemen dalam pengembangan strategi terutama prioritas strategi dan perencanaan tindakan sehingga sesuai dengan misi perusahaan dan kepentingan seluruh pemangku kepentingan. Strategi ini harus mempunyai focus pengembangan jangka pendek, menengah dan panjang. Board harus secara aktif memonitor pelaksanaan strategi dan rencana bisnis yang telah disetujui termasuk kecukupan komunikasi dan pelaporan internal dan eksternal serta memenuhi aspek keterbukaan

c) Kinerja: Board mengkaji dan menyetujui strategi perusahaan, rencana kerja tahunan dan rencana keuangan tahunan. Board juga memantau secara aktif hasil capaian kinerja manajemen dibandingkan dengan budget dan capaian sasaran strategis perusahaan

d) Integritas: Board harus menetapkan arahan mengenai pemahaman etika dalam perusahaan dan mewajibkan manajemen untuk menetapkan kebijakan praktis terhadap penerapan standar kejujuran, integritas dan perilaku etis serta kepatuhan terhadap peraturan perundangan. Ini dapat dalam bentuk pedoman etika bisnis dan perilaku, kebijakan kepatuhan, pedoman Whistleblowing System, panduan pengendalian kecurangan

e) Kaderisasi: Board menyeleksi, mengangkat, mengevaluasi dan menetapkan kompensasi dari CEO serta melakukan supervisi langsung terhadap program kaderisasi khsususnya untuk calon - calon pimpinan perusahaan termasuk suksesi CEO. Board hendaknya menyampaikan pola kompensasi eksekutif secara jelas kepada yang bersangkutan

f) Risk Governance: Board memahami dan memantau dengan cermat paparan resiko perusahaan terutama resiko strategis, resiko operasi, resiko financial dan resiko kepatuhan. Board bersama-sama dengan manajemen menetapkan tingkatan selera resiko, toleransi resiko selaras dengan prioritas strategi perusahaan. 


\section{METODE PENELITIAN}

\section{a) Lokasi dan Informan Penelitian}

Penelitian ini dilakukan pada kantor PDAM Kabupaten Bantul. Dalam penelitian kualitatif, hal yang menjadi bahan pertimbangan utama dalam pengumpulan data adalah pemilihan informan. Seperti yang telah disebutkan bahwa pemilihan informan merupakan hal yang sangat utama sehingga harus dilakukan secara cermat, karena penelitian ini mengkaji tentang prosedur implementasi prinsip-prinsip good corporate governance dalam program corporate social responsibility maka peneliti memutuskan informan dalam penelitian ini adalah dewan komisaris, dewan direksi, karyawan, dan masyarakat yang wilayahnya menjadi program corporate social responsibility PDAM Kabupaten Bantul.

\section{b) Teknik Pengumpulan Data}

1) Pengumpulan data primer

a. Observasi

Dalam penelitian ini, peneliti hendak melakukan observasi di PDAM Kabupaten Bantul. Dengan dilaksanakannya observasi diharapkan peneliti dapat mengamati gejala-gejala atau peristiwa yang terjadi dilokasi yang diteliti. Sehingga diharapkan bisa menambah informasi-informasi atau data-data yang diperlukan dalam penelitian ini.

b. Wawancara

Untuk memperoleh data dalam penelitian kualitatitf yaitu salah satunya dengan metode wawancara dengan langkah-langkah melalui dari menetapkan siapa yang akan diwawancara sampai akhirnya mengidentifikasi data yang didapatkan. Langkah-langkah ini dilakukan dalam penelitian ini dimana peneliti akan melakukan wawancara kepada para stakeholder PDAM Kabupaten Bantul guna untuk mempermudah dalam proses pencarian data sehingga data yang didapat akan sesuai dengan kondisi fakta-fakta yang terjadi. Dengan data-data yang sesuai maka akan mempermudah jalannya penelitian.

2) Pengumpulan data sekunder

Pengumpulan data dan informasi maupun teori melalui buku-buku acuan relevan yang mendukung hal-hal bersangkutan dengan objek penelitian (Tjahjono, 2015). Data yang diperoleh melalui tinjauan keperpustakaan dijadikan acuan utama bagi peneliti, data tersebut berupa buku-buku, jurnal, maupun dokumen-dokumen yang berhubungan dengan penelitian di PDAM Kabupaten Bantul.

\section{c) Definisi Operasional Variabel Penelitian}

\section{Good Corporate Govenance (GCG)}

Good Corporate Governance (GCG) adalah hubungan antara manajemen atas perusahaan yaitu yang terdiri dari $\mathrm{BoD}$, manajer senior, dan pemangku kepentingan yang mana merupakan mekanisme yang memberikan wewenang untuk mengendalikan perusahaan berdasarkan keputusan yang diambil oleh manajemen atas (Pintea, 2015). Implementasi good corporate governance dideskripikan dan dianalisis menggunakan model deloitte governance framework. Model ini adalah budaya perusahaan risiko yang akan mempengaruhi ataupun berdampak pada efektivitas dari seluruh elemen kerangka kerja. Keberhasilan dan kegagalan perusahaan sering kali sangat ditentukasn bagaimana dalam menegelola paparan risiko yang dihadapainya karena hal tersebut merupakan budaya mengelola risiko menjadi inti dari kerangka kerja governance. Model ini terdiri dari dua bagian, yaitu corporate governance infrastructure dan board governance (Susilo, 2017). 


\section{Corporate Social Responsibility (CSR)}

Corporate Social Responsibility (CSR) adalah komitmen berkelanjutan dalam hal bisnis agar sesuai dengan etika yang berhubungan dengan masyarakat luas dan pemangku kepentingan. CSR menorong perusahaan untuk menyeimbangkan hubungan antara karyawan, pelanggan, komunitas, pemerintah, dan masyarakat luas (Stuebs and Li, 2015).

\section{d) Teknik Analisis Data}

\section{Uji Triangulasi}

Pada penelitian ini akan dilakukan triangulasi data dengan dua pendekatan; pertama adalah triangulasi teknik dimana menggunakan teknik yang berbeda yaitu wawancara, observasi dan dokumen; kedua adalah triangulasi sumber yaitu menguji kredibilitas data dengan cara mengecek data yang diperoleh melalui beberapa sumber.

\section{Uji Obyektivitas}

Data penelitian kualitatif dikatakan memiliki obyektifitas yang tinggi bilamana data hasil penelitian tersebut telah disahkan dan ditegaskan oleh banyak pihak. Dalam hal ini peneliti akan memaparkan data-data secara obyektif dengan menunjukan bukti-bukti hasil penemuan yang diperoleh. Pada prinsipnya analisa data merupakan proses mengolah dan menyusun data secara sistematis untuk mudah diinterpretasikan. Untuk mengolah data secara mudah, maka dilakukan dua tahap analisis data, yaitu:

a. Reduksi Data

Bisa juga dikatakan memilah dan memilih data, dimana data-data yang telah terkumpul dipecah dalam satuan (datum) dan dipilih yang relevan dan membuang yang tidak perlu. Setelah semua selesai, lalu diberi kode yang dimengerti oleh peneliti (Moleong, 2007).

b. Kategorisasi Data

Setelah data-data yang relevan diberi kode, lalu dibentuk kategori relevan, dan nantinya datum tersebut dikelompokkan kembali sesuai kategori data yang sesuai dengan penelitian.

c. Penarikan Kesimpulan

Peneliti berusaha untuk menarik kesimpulan-kesimpilan tersebut dengan longgar, keterbukaan dan skeptic, tetapi kesimpulan yang ada pada awalnya belum jelas namun kemudian meningkat lebih rinci dan mengakar dengan kokoh. Penarikan kesimpulan juga bisa dilakukan ketika proses pengumpulan data, kemudian dilakukan reduksi serta penyajian data, maka akan dapat ditarik kesimpulan.

\section{HASIL PENELITIAN DAN PEMBAHASAN}

\subsection{Peran Dewan Komisaris, Direksi, Dan Stakeholder Dalam Pengembangan GCG di PDAM Bantul}

Untuk dapat menerapkan prinsip - prinsip Good Corporate Governance (GCG) dengan baik maka diperlukan sinergi yang baik antara dewan komisaris, direksi, dan juga stakeholder (Effendi, 2016). Oleh karena itu peran dewan komisaris, direksi, dan stakeholder dari PDAM Bantul diteliti dalam rangka pengembangan kerangka operasional GCG. PDAM Bantul menerapkan prinsip dan peraturan bahwa setiap bagian perusahaan bertanggung jawab atas menjalankan tugas masing - masing selaras dengan visi, misi dan strategi perusahaan. Peraturan tersebut harus ditaati oleh semua bagian dari PDAM Bantul dan tidak terkecuali untuk dewan komisaris, direksi, dan stakeholder. Hal ini agar setiap organ perusahaan mampu 
mempertanggungjawabkan kinerja masing - masing sesuai bidangnya. Setiap bagian perusahan mempunyai tanggung jawab sesuai dengan tugas, dan peranan masing masing dibidangnya untuk mewujudkan kinerja perusahaan yang baik.

Dewan komisaris, direksi, dan stakeholder memiliki porsi peran masing-masing dalam rangka pengembangan kerangka operasional GCG di PDAM Bantul. Pertama, Dewan Komisaris dalam rangka pengembangan kerangka operasional GCG memiliki peran yaitu mengawasi Direksi di PDAM Bantul dalam mencapai kinerja dalam business plan dan memberikan nasehat kepada Direksi mengenai penyimpangan pengelolaan usaha yang tidak sesuai dengan arah yang ingin dituju oleh perusahaan. Dewan Komisaris melakukan pengawasan terhadap pengelolaan di PDAM Bantul melalui supervise, pemberian panduan dan nasihat kepada Direksi. Setiap anggota Dewan Komisaris bertindak mandiri dalam memenuhi tugas dan tanggung jawabnya kepada Perseroan.Tidak satupun komisaris mempunyai hubungan keluarga, keuangan, manajemen dan/atau kepemilikan saham dengan anggota Dewan Komisaris lainnya ataupun dengan anggota Direksi. Dewan Komisaris bertanggung jawab kepada pemegang saham. Kemudian, Komisaris juga berperan dalam memantau penerapan dan efektivitas dari praktek GCG di PDAM Bantul.

Kedua, Direksi (board) dalam rangka pengembangan kerangka operasional GCG di PDAM Bantul berperan dalam rangka menetapkan struktur dan proses dengan mempertimbangkan sudut pandang investor, regulator, dan manajemen. Direksi berperan sebagai penanggungjawab dalam penerapan dan pemantauan GCG di PDAM Bantul yaitu berperan dalam penyusunan program - program terkait dengan CSR, board tidak terlepas dari adanya peran mereka alam menetapkan sebuah keputusan dan kebijakan dari suatu program CSR. Direksi juga wajib membangun dan melaksanakan program manajemen resiko di PDAM BAntul secara terpadu yang merupakan bagian dari pelaksanaan GCG. Direksi berperan melakukan implementasi prinsip-prinsip GCG dalam setiap aktivitas bisnis perusahaan, serta dapat mengarahkan dan melakukan koordinasi pelaksanaan kegiatan operasional perusahaan, dan juga melakukan penanganan terhadap perencanaan, pengelolaan dan pelaporan keuangan secara efektif, efisien dan terpercaya demi menjamin ketersediaan dana dalam rangka menunjang seluruh kegiatan usaha perusahaan. Pada perusahaan PDAM Bantul, Direksi (board) saling berintegrasi satu sama lain, dan juga memiliki koordinasi dari segi sudut pandang investor, regulator, dan manajemen untuk mendukung setiap kegiatan perusahaan dalam rangka mewujudkan Good Corporate Governance (GCG).

Ketiga, Stakeholder merujuk pada semua pemangku kepentingan perusahaan yaitu seluruh organ dalam perusahaan, seluruh karyawan, masyarakat, serta pemerintah. Jadi dalam membahas peran stakeholder dalam rangka pengembangan kerangka operasional GCG di sebuah perusahaan dapat diartikan kedalam lingkup yang sangat luas. Stakeholder di PDAM Bantul berperan untuk saling mengawasi antara satu pihak dengan pihak lain agar perusahaan dapat bertahan dalam menjalalankan Good Corporate Governance (GCG). Stakeholder di PDAM Bantul telah mampu membuktikan bahwa telah melaksanakan perannya selama ini dengan sangat baik terlihat dimana terdapat suatu sinergi yang sangat baik diantara Dewan Komisaris, Dewan Direksi, seluruh karyawan, masyarakat, dan pemerintah yang memberikan hasil yang sangat maksimal yaitu PDAM Bantul telah mampu menerapkan seluruh prinsipprinsip Good Corporate Governance (GCG)

\subsection{Design Kerangka Operasional GCG di PDAM Bantul}

Coombs dan Sherry (2012) berpendapat bahwa perusahaan yang ingin dapat meraih Good Corporate Governance (GCG) harus menciptakan komunikasi yang sangat baik diantara para stakeholder di perusahaan. Para stakeholder dalam perusahaan selain harus pandai dan bijak dalam berkomunikasi juga harus mampu menjadi pendengar yang baik bagi sesama stakeholder. Terdapat hubungan yang sangat erat diantara Good Corporate Governance (GCG) 
dengan Corporate Social Responsibility (CSR) dimana ketika sebuah perusahaan telah mampu menerapkan prinsip GCG dengan paripurna maka perusahaan tersebut juga akan mampu merumuskan program CSR serta mengimplementasikan program CSR dengan sangat baik dan benar-benar berdampak positif bagi lingkungan dan masyarakat.

Pada model Deloitte Governance, mampu menjadi jembatan bagi Good Corporate Governance (GCG) dan Corporate Social Responsibility (CSR). Model Deloitte Governance terdiri dari dua komponen inti yaitu Board Governance dan Corporate Governance Infrastructure yang diwakili oleh sembilan elemen utama yaitu empat elemen dari infrastruktur terdiri dari Planning (Perencanaan), Operations (Operasi), Reporting (Pelaporan), Compliance (Kepatuhan) dan lima elemen internal yang terdiri dari Performance (Kinerja), Strategy (Strategi), Governance (Tata kelola), Talent (Talenta), Integrity (Integritas) (Susilo, 2017). Ketika sebuah perusahaan ingin menerapkan Model Deloitte Governance, maka Komisaris dan Direksi harus mampu berkolaborasi untuk mampu mengendalikan elemen-elemen terdapat dalam Corporate Governance Infrastructure dimana Komisaris dan Direksi harus mampu mengendalian semua kegiatan di perusahaan yang terkait dengan perencanaan, dan operasi serta harus mampu memantau dengan baik seluruh kinerja perusahaan, strategi serta tata kelola perusahaan. Model Deloitte Governance tersebut merupakan model yang sangat tepat untuk dijadikan acuan dalam mendesain kerangka pengembangan GCG PDAM Bantul. PDAM Bantul dapat memaksimalkan peran dari Direksi dan Komisaris agar mampu mengendalikan dan mengawasi kegiatan perseroan sesuai dengan kerangka yang ditawarkan oleh Model Deloitte Governance agar perusahaan lebih dapat maksimal dalam merumuskan serta mengimplementasikan Corporate Social Responsibility (CSR).

\subsection{Implementasi Good Corporate Governance pada Program CSR PDAM Bantul}

Implementasi good corporate governance dideskripikan dan dianalisis menggunakan model deloitte governance framework. Model ini adalah budaya perusahaan risiko yang akan mempengaruhi ataupun berdampak pada efektivitas dari seluruh elemen kerangka kerja. Keberhasilan dan kegagalan perusahaan sering kali sangat ditentukann bagaimana dalam menegelola paparan risiko yang dihadapainya karena hal tersebut merupakan budaya mengelola risiko menjadi inti dari kerangka kerja governance. Model ini terdiri dari dua bagian, yaitu corporate governance infrastructure dan board governance (Susilo, 2017).

Peran board harus menetapkan suatu struktur dan proses agar dapat menunaikan tugas dan tanggung jawabnya antara lain dengan mempertimbangkan sudut pandang investor, regulator, dan manajemen. Pada perusahaan PDAM Bantul, pihak board sama - sama saling berintegrasi satu sama lain, dan juga memiliki koordinasi dari segi sudut pandang investor, regulator, dan manajemen. Dalam pelasanaan program CSR yang sudah diatur dengan jelas dalam peraturan menteri BUMN No PER-05/MBU/27 April 2007 tentang program kemitraan BUMN dengan usaha kecil dan program bina lingkungan.Menurut Model Deloitte peran board harus menetapkan suatu struktur dan proses agar dapat menunaikan tugas dan tanggung jawabnya antara lain dengan mempertimbangkan sudut pandang investor, regulator, dan manajemen, hal tersebut dapat dikaitkan dengan pelaksanaan program CSR. Hal ini dibuktikan dengan penemuan oleh peneliti bahwa dalam penyusunan program - program terkait dengan CSR, board tidak terlepas dari adanya peran mereka alam menetapkan sebuah keputusan dan kebijakan dari suatu program CSR. Selain itu perusahaan PDAM Bantul memiliki fokus pengembangan strategi jangka pendek, menengah, dan panjang, yang sudah dibagi - bagi. Hal tersebut akan menjadikan perusahaan mudah mendapatkan hasil dari strategi berupa tujuan jangka pendek, menengah, dan panjang pula. 


\section{Rencana Jangka Pendek}

Membangun kerjasama atas kemitraan usaha secara profesional dan proposional degan badan, institusi/intansi, lembaga yang terkait, guna berperan serta pada program pembangunan nasional.

\section{Rencana Jangka Menengah}

Dalam memprioritaskan perencanan jangka menengah PDAM Bantul lebih menekankan pada kualitas produk dan pelayanan customer untuk memperkuat posisi dasar dan menentukan peluang- peluang bisnis yang ada.

\section{Rencana Jangka Panjang}

Mensukseskan program Pembangunan Ekonomi Nasional, khususnya di bidang air minum dan pelayanan kebutuhan air bersih kepada warga Bantul dan sekitarnya, sesuai dengan target dan sasaran pencapaian pelayanan.

Dalam prakterk CSR yang sudah dilakukan oleh PDAM Bantul, hal ini sudah memiliki adanya strategi jangka panjang. Nilai perusahaan yang tinggi merupakan tujuan jangka panjang yang seharusnya dicapai perusahaan dengan harga saham yang tinggi, hal tersebut berkaitan mengenai pentingnya penerapan prinsip - prinsip good corporate governance, khususnya pada perusahaan pemerintah, program corporate sosial responsibility memainkan peranan penting bagi perusahaan dimana ada keterkaitan dengan nilai perusahaan. Hal ini mencakup strategi jangka panjang dimana perusahaan hidup di lingkungan masyarakat dan aktivitasnya memiliki dampak sosial dan lingkungan. Adanya kecukupan komunikasi, PDAM Bantul menggunakan sarana teknologi seperti website dan juga beberapa spanduk untuk terkait program - program CSR nya. Direktur PDAM Kabupaten Bantul Drs. Yudi Indarto, M.M menjelaskan, tahun 2018 mengangkat tema : BUMD Hebat, Kunci Percepatan Pertumbuhan Ekonomi Indonesia. Dalam ajang bergengsi itu PDAM Bantul mendapatkan penghargaan TOP BUMD 2018 itu karena kinerjanya dinilai cukup baik, ada beberapa aspek penilaian karena PDAM Bantul dianggap telah melakukan terobosan baru, khususnya dalam berinovasi pelayanan publik berbasis android dengan diberi nama "SIAP PRIMA" Terobosan itu juga dapat diunduh melalui google play store dengan mengetik PDAM Bantul.

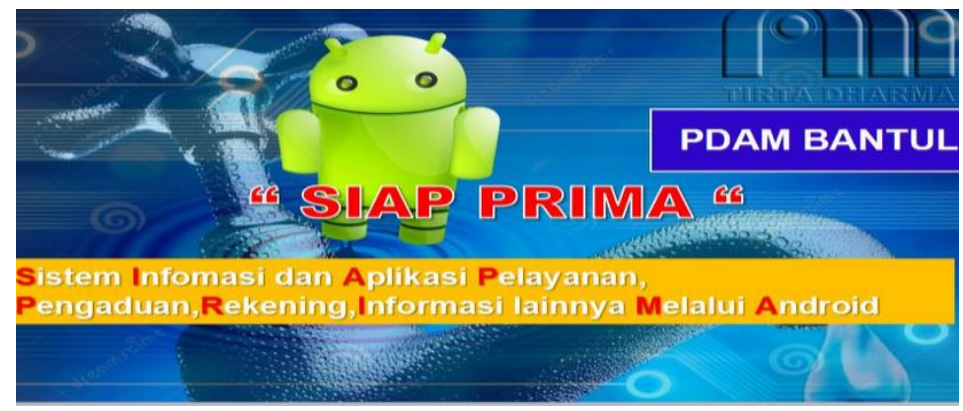

Gambar 2. Aplikasi SIAP PRIMA PDAM Bantul

(Sumber : Data Primer Diolah, 2018)

Hal tersebut adalah bentuk dari strategi-strategi perusahaan dalam menginovasikan dari sisi teknologi. Hal tersebut juga dikaitkan dengan analisis risiko, yang dimana sekarang ini semua perusahaan sudah memasuki era digitalisasi, yang artinya perusahaan PDAM Bantul secara cepat dan tanggap memakai strategi inovasi dari sisi teknologi ini untuk memberikan bukti real untuk menghadapi persaingan bisnis yang ketat di masa era digital saat ini. Tidak hanya itu pencapaian spektakuler lainnya adalah keuntungan, saldo kas dan jumlah pelanggan selalu meningkat setiap tahunnya dan hasil audit independen WTP. 


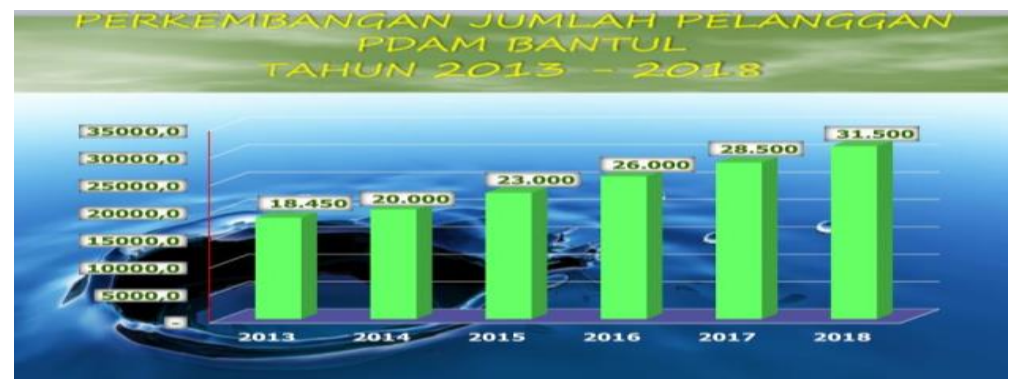

Gambar 3. Perkembangan Jumlah Pelanggan PDAM Bantul 2013-2018

(Sumber : Data Primer Diolah, 2018)

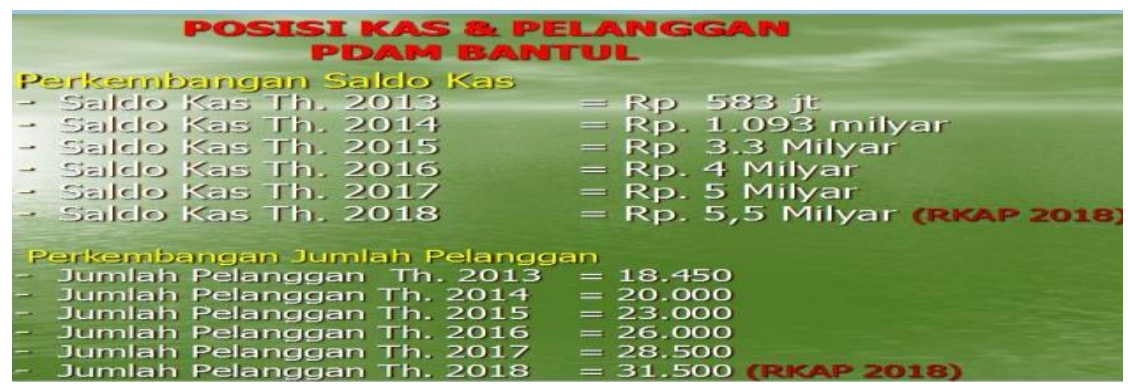

Gambar 4. Posisi Saldo Kas dan Pelanggan PDAM BANTUL (Sumber : Data Primer Diolah, 2018)

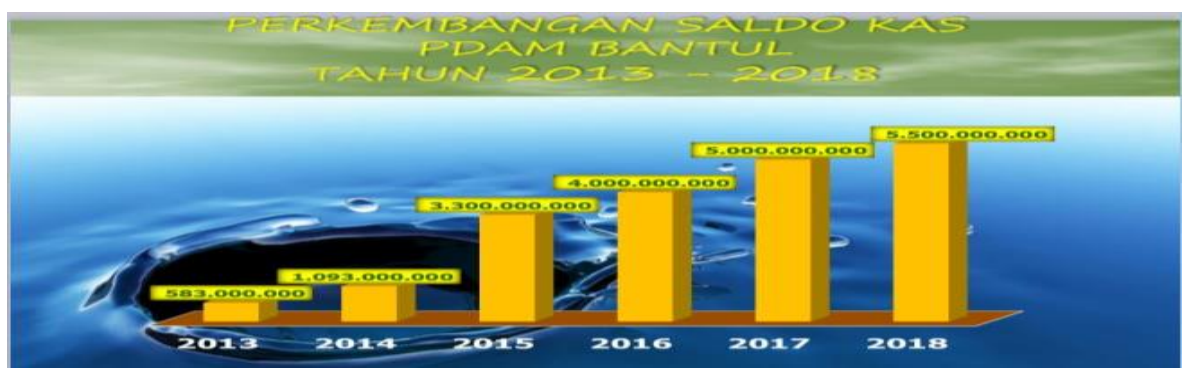

Gambar 5. Perkembangan Saldo Kas PDAM Bantul Tahun 2013-2018 (Sumber : Data Primer Diolah, 2018)

Dalam model Deloitte, board mengkaji dan menyetujui strategi perusahaan, rencana kerja tahunan, serta rencana keuangan tahunan. Pihak board juga memantau secara aktif hasil capaiaan kinerja manajemen dibandingkan dengan budget dan capaian kinerja manajemen dibandingkan dengan budget dan capaian sasaran strategis perusahaan yang telah ditetapkan.

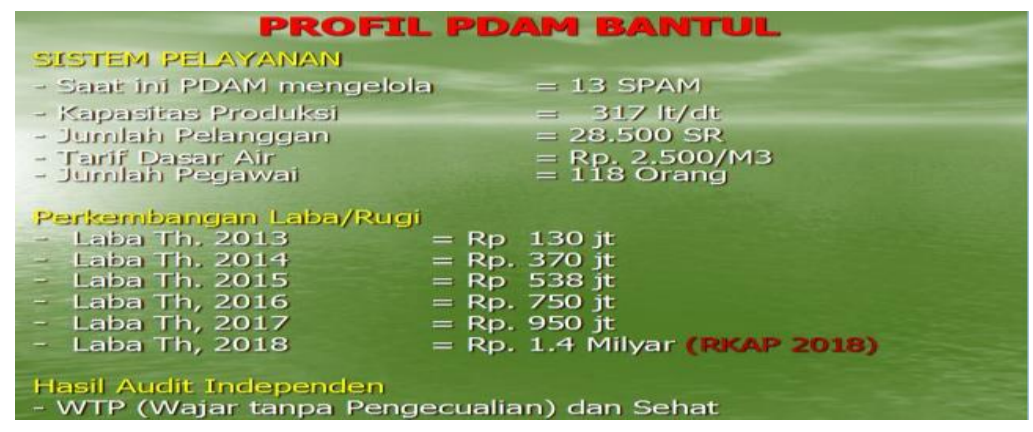

Gambar 6. Hasil Audit Independen PDAM Bantul

(Sumber : Data Primer Diolah, 2018) 
Dari gambar diatas menunjukkan laba yang diperoleh PDAM Bantul secara signifikan mengalami peningkatan secara terus menerus dengan angka yang cukup besar dalam peningkatannya. Hal tersebut disebabkan oleh adanya tentu peningkatan dari kinerja PDAM Bantul. Diikuti dengan adanya peningkatan pelanggan, tentu membuktikan bahwa PDAM Bantul memberikan adanya branding dan positioning yang baik bagi pelanggan, sehingga menimbulkan keterpercayaan dan makin meningkatkan nilai dari perusahaan.

Peningkatan kinerja dari PDAM Bantul juga tidak lepas dari kerjasama antara Dewan Direksi, Dewan Komisaris, dan juga stakeholder yang berkomitmen tinggi untuk menerapkan prinsip Good Corporate Governance $(G C G)$ dalam rangka mengimplementasikan program-program CSR yang telah dirancang oleh seluruh stakeholder di PDAM Bantul. Board menetapkan arahan mengenai pemahaman etika dalam perusahaan dan mewajibkan manajemen untuk menetapkan kebijakan praktis terhadap penerapan standar kejujuran, integritas, dan perilaku etis serta kepatuhan terhadap peraturan perundangan. Hal ini dapat dalam bentuk pedoman etika bisnis dan perilaku, kebijakan kepatuhan, pedoman whistleblowing system, panduan pengendalian kecurangan.

Manajemen melaksanakan program perencanaan dengan cara melihat dari sisi profit dan juga risikonya. Kemudian dalam pelaksanaan, manajemen melaksanakan pengelolaan perusahaan dengan menyesuaikan apa yang dilaksanakan sesuai dengan apa yang direncanakan sesuai SOP yang ada. Pelaksanaan itu juga diikuti dengan adanya pelaporan mengenai kenyataan dari pelaksanaan kegiatan perusahaan, kemudian disesuaikan dengan tujuan dan standar-standar yang sudah ditentukan. Dengan adanya pelaporan tersebut kemudian dilihat bagiamana perusahaan menjalankan kegiatannya dalam koridor kepatuhan terhadap hukum dan peraturan perundangan serta norma berlaku. Untuk mencapai tujuantujuan tersebut perusahaan perlu memiliki pedoman perilaku (code of conduct) yang berlaku bagi seluruh jajaran perusahaan baik dewan Komisaris, Direksi maupun seluruh karyawan. Perilaku etis dan berintegritas yang diperlihatkan direksi dan seluruh manajemen adalah prasyarat untuk terbentuknya perilaku etis oleh seluruh karyawan dalam setiap seluruh aspek kegiatan perusahaan.

Pengendalian internal yang efektif dimulai dengan kepatuhan terhadap standar-standar etika yang berlaku di perusahaan baik dalam bentuk lisan ataupun tulisan. Board menetapkan arahan mengenai pemahaman etika dalam perusahaan dan mewajibkan manajemen untuk menetapkan kebijakan praktis terhadap penerapan standar kejujuran, integritas, dan perilaku etis serta kepatuhan terhadap peraturan perundangan. Hal ini dapat dalam bentuk pedoman etika bisnis dan perilaku, kebijakan kepatuhan, pedoman whistleblowing system, panduan pengendalian kecurangan. Dalam prinsip GCG, dalam melaksanakan kegiatannya perusahaan senantiasa memperhatikan kepentingan pemegang saham dan stakeholders. Dalam pelaksanaan kegiatan usaha perusahaan seringkali hakhakstakeholders tidak dapat terlaksana dengan baik sehingga menimbulkan friksi antarastakeholders dengan Perusahaan yang ditunjukkan dengan munculnya pelaporan pelanggaran oleh stakeholders.

PDAM Bantul memandang pedoman dan prosedur penanganan pelaporan pelanggaran (Whistleblowing) merupakan bagian dari sistem pengendalian internal. PDAM Bantul senantiasa memperhatikan kepentingan stakeholders berdasarkan asas kewajaran dan kesetaraan. Perusahaan juga menyadari bahwa tidak adanya mekanisme standar dalam penanganan pelaporan pelanggaran oleh stakeholders dapat berakibat menurunkan reputasi dan kepercayaan masyarakat pada perusahaan. Ketentuan-ketentuan dalam pedoman dan prosedur pelaporan pelanggaran ini merupakan salah satu bentuk peningkatan perlindungan terhadap stakeholders dan perlindungan terhadap nama baik perusahaan. Pelaporan pelanggaran dilakukan secara tertulis dengan menyampaikan surat resmi yang ditujukan 
kepada perusahaan, dengan cara diantar langsung, dikirim melalui facsimile, atau melalui pos ke perusahaan.

Sampai saat ini PDAM Bantul dapat membuktikan bahwa korporatnya merupakan salah satu BUMN yang memiliki integritas yang sangat tinggi baik para Dewan Komisaris, Dewan Direksi, dan juga seluruh stakeholdernya dibuktikan dengan program-program CSR yang semakin maju dan mampu memberikan dampak yang baik bagi lingkungan sekitar. Board meyeleksi, mengangkat, mengevaluasi, dan menetapkan kompensasi. Proses kaderisasi di PDAM Bantul dilaksanakan oleh pihak SDM dari mengangkat, mengevaluasi, higga menetapkan kompensasi. Kompensasi untuk CEO biasanya didiskusikan oleh pihak kompensasi dari dewan direktur setelah CEO mempresentasikan rekomendasi kompensasi untuk bawahannya. Dari presentasi ini, sikap dasar CEO tentang keinginan presentase tertentu atas kompensasi insentif yang diberikan bisa dilihat nantinya. Dalam keadaan biasa panitia secara sederhana menerapakan presentase yang sama untuk kompensasi CEO. Namun, panitia biasanya memberi tanda untuk kinerja CEO yang berbeda dengan memutuskan apakah memberikan presentase yang lebih tinggi atau lebih rendah.

Kaderisasi memiliki hubungan yang sangat erat dengan kinerja para Board dan juga stakeholder perusahaan dimana keduanya berhubungan langsung. Ketika sistem kaderisasi di PDAM Bantul dilakukan sesuai dengan prosedur serta memenuhi persyaratan yang ada maka secara otomatis kinerja dari perusahaan pun akan meningkat. Ketika kinerja meningkat berarti hal itu menandaka bahwa PDAM Bantul telah mampu menerapkan prinsip Good Corporate Governance (GCG) dengan baik dan dengan GCG yang terlaksana dengan baik maka hasil implentasi dari program CSR yang sudah dirancang dengan seksama juga akan maksimal.

Risk governance dari model Deloitte terdapat kesesuaian dengan praktek di PDAM Bantul yang dimana pihak board memahami dan memantau dengan cermat paparan risiko perusahaan, terutama, risiko strategis, risiko operasi, risiko finansial. PDAM mengelola sebuah resiko dengan beberapa upaya, Yang pertama dengan mengidentifikasi unsur-unsur ketidakpastian dan tipe-tipe resiko yang dihadapi. Kedua berusaha untuk menghindari dan menanggulangi semua unsur ketidakpastian dengan membuat perencanaan tahunan dengan baik dan cermat. Ketiga berusaha untuk mengetahui hubungan dan konsekuensi antar peristiwa sehingga dapat diketahui resiko-resiko yang terkandung di dalamnya. Keempat berusaha untuk mencari dan mengambil langkah-langkah untuk menangani resiko-resiko yang telah berhasil diidentifikasi.

PDAM mengacu pada Peraturan Menteri Negara BUMN No PER-01?MBU/2011 tanggal 1 Agustus 2011 tentang Penerapan Tata Kelola Perusahaan yang baik pada BUMN pada bagian keenam pasal 25 disebutkan bahwa Direksi dalam setiap pengambilan keputusan harus mempertimbangkan resiko usaha, Direksi wajib membangun dan melaksanakan program manajemen resiko korporasi secara terpadu yang merupakan bagian dari pelaksanaan GCG, Pelaksanaan program manajemen resiko dapat dilakukan dengan membentuk unit kerja tersendiri yang ada dibawah direksi serta member penugasan kepada unit kerja yang ada dan relevan untuk menjalankan fungsi manajemen resiko, Direksi wajib menyampaikan laporan profil manajemen resiko dan penanganannya bersamaan dengan laporan berkala perusahaan.

Tata kelola resiko menjadi tanggung jawab manajemen, untuk menyelenggarakan tatakelola manajemen resiko dan memastikan bahwa praktik manajemen resiko terselenggara di seluruh perusahaan maka harus meliputi unsure-unsur kebijakan manajemen resiko, akuntabilitas pelaksanaan, perencanaan manajemen resiko terpadu, penyediaan sumber daya yang memadai dan mekanisme komunikasi serta pelaporan pelaksanaan manajemen resiko baik internal maupun eksternal. Kebijakan manajemen 
resiko merupakan pernyataan komitmen secara tertulis oleh direksi dan dewan komisaris untuk melaksanakan manajemen resiko dalam organisasi. (penentuan standar atau metode yang digunakan, komitmen untuk melaksanakan review dan verifikasi secara berkala terhadap efektivitas penerapan manajemen resiko).

PDAM Bantul telah mampu menerapkan prinsip-prinsip yang terkandung di dalam Good Corporate Governance (GCG) yang menandakan bahwa PDAM Bantul telah mampu meminimalisir resiko yang mungkin muncul ataupun terjadi sehingga ketika resiko dapat diminimalisir maka PDAM Bantul juga akan maksimal dalam menerapkan program CSR.Komponen utama dari model Deloitte Governnace terdiri dari dua yaitu Board Governance dan Corporate Governance Infrastructure yang yang diwakili oleh sembilan elemen utama yaitu empat elemen dari infrastruktur terdiri dari Planning (Perencanaan), Operations (Operasi), Reporting (Pelaporan), Compliance (Kepatuhan) dan lima elemen internal yang terdiri dari Performance (Kinerja), Strategy (Strategi), Governance (Tata kelola), Talent (Talenta), Integrity (Integritas). PDAM Bantul dari sudut pandang menggunakan model Deloitte Governance sudah mampu mengelola kesembilan elemen dengan baik sehingga praktek Good Corporate Governance (GCG) dari PDAM Bantul terlaksana dengan baik dan terlebih lagi dengan baiknya penerapan prinsip GCG maka program CSR yang telah dirancang oleh PDAM Bantul dapat terlaksana dengan baik.

\section{KESIMPULAN DAN SARAN}

\section{Kesimpulan}

Dari hasil penelitian ini dapat disimpulkan bahwa:

1. Dewan komisaris, direksi, dan stakeholder memiliki porsi peran masing-masing dalam rangka pengembangan kerangka operasional GCG di PDAM Bantul. Dewan Komisaris memiliki peran yaitu mengawasi Direksi di PDAM Bantul dalam mencapai kinerja dalam business plan dan memberikan nasehat kepada Direksi mengenai penyimpangan pengelolaan usaha yang tidak sesuai dengan arah yang ingin dituju oleh perusahaan. Direksi (board) berperan dalam rangka menetapkan struktur dan proses operasional perusahaan, penanggungjawab dalam penerapan dan pemantauan GCG, penyusunan program CSR, dan implementasi prinsip-prinsip GCG dalam setiap aktivitas bisnis perusahaan. Stakeholder di PDAM Bantul berperan untuk saling mengawasi antara satu pihak dengan pihak lain agar perusahaan dapat bertahan dalam menjalalankan Good Corporate Governance (GCG)

2. Design kerangka operasional GCG yang diterapkan oleh PDAM Bantul tidak terlepas dari hubungan erat antara stakeholder dan Corporate Social Responsibility (CSR). Stakeholder berperan penting dalam rangka menumuskan, menyusun, serta mengimplementasikan programprogram CSR. Dalam menyusun progam CSR yang akan diimplementasikan oleh PDAM Bantul, para stakeholder juga sangat ditunjang dengan adanya penerapan prinsip - prinsip GCG yang juga didasarkan pada model Deloitte Governance sehingga memudahkan bagi PDAM Bantul dalam mengimplementasikan program CSR yang sudah dirancang dengan matang.

3. PDAM Bantul dari sudut pandang menggunakan model Deloitte Governance sudah mampu mengelola kesembilan elemen dengan baik sehingga praktek Good Corporate Governance (GCG) dari PDAM Bantul terlaksana dengan baik dan terlebih lagi dengan baiknya penerapan prinsip GCG maka program CSR yang telah dirancang oleh PDAM Bantul dapat terlaksana dengan baik. 


\section{Saran}

Penelitian ini akan mencoba menyampaikan beberapa saran yang didasari oleh hasil analisis data dan pembahasan yang telah dilakukan. Saat ini ditujukan kepada pihak-pihak yang terkait seperti:

1. Saran bagi PDAM Kabupaten Bantul

Program CSR yang dilakukan PDAM Bantul belum dirasa optimal dikarenakan informasi CSR yang sangat minim dan belum disampaikan secara terbuka mengingat praktek Good Corporate Governanne (GCG) yang sudah dipraktekkan dengan baik yaitu terbukti dengan prinsip dasar GCG yang berhasil diimplementasikan oleh Board dan stakeholder. PDAM Bantul akan lebih baik apabila memberikan informasi yang lengkap dan rinci mengenai kegiatan CSR yang dilakukan. Menjalin kerjasama dengan pihak internal juga dapat dilakukan oleh PDAM Bantul agar dapat mewujudkan program CSR yang lebih baik.

2. Saran bagi akademisi

Perlu adanya penambahan kerangka prosedur agar mampu melengkapi kerangka prosedur model Deloitte Governance dan juga akan lebih baik apabila menambah prinsip-prinsip yang digunakan sebagai dasar Good Corporate Governance (GCG) agar lebih lengkap dan mewakili GCG secara maksimal.

\section{DAFTAR PUSTAKA}

Coombs, T., and Sherry J.H., (2012), Managing Corporate Social Responsibility A Communication Approach. Chichester : Wiley-Blackwell.

Effendi, A., (2016), The Power Good Corporate Governance. Edisi 2. Jakarta: Salemba Empat.

Moleong, L.J., (2007), Metodologi Penelitian Kualitatif. Penerbit PT Remaja Rosdakarya Offset, Bandung.

Pintea, M.O., (2015), Transparency Of Local Budgets In The North- West Region of Romania. Annuals of the University of Oradea, Economic Science Series.

Stuebs, M., Sun Li., (2015), Corporate Governance and Social Responsibility. Journal of Law and Management, Vol 38, No 52.

Susilo, L., (2017), Governance, Risk Management and Compliance. Jakarta: PT Grafindo

Tjahjono, H.K., (2015), Metode Penelitian Bisnis. VSM MM UMY 